\title{
Harvesting and Supply Chain Analysis of Ethnobotanical Species in the Pachmarhi Biosphere Reserve of India
}

\author{
Chandra Prakash Kala* \\ Ecosystem \& Environment Management, Indian Institute of Forest Management, Nehru Nagar, Bhopal, India \\ *Corresponding author: cpkala@yahoo.co.uk \\ Received December 28, 2012; Revised February 01, 2013; Accepted April 02, 2013
}

\begin{abstract}
Realizing the historical importance of central Indian forests in terms of ecological, social and economical perspectives and the present socio-economic changes in the community due to several reasons, the present study was conducted. It aimed at addressing the status of harvesting pattern and supply chain structure of various ethno-botanical species by the tribal communities in the Pachmarhi Biosphere Reserve of India. The questionnaire surveys were conducted in the villages of buffer zone areas of the Pachmarhi Biosphere Reserve and market places for studying the trends and status of collection, seasons of collection, prices, and supply chain of ethnobotanicals. A total 14 ethno-botanical species were found in active trade, and in majority of cases their gum, fruit and seed were collected. The gum yielding species such as Acacia nilotica, Anogeissus latifolia, Sterculia urens, Terminalia tomentosa and Terminalia arjuna were found to be highly paid species among all traded ethno-botanical species. The trade in ethnobotanicals and market trends seemed quite lucrative to the tribal communities and hence they have started unsustainable harvesting of tradable forest resources to get maximum returns unlike their ancestors. Of the total tradable ethnobotanical species 8 species have qualified to various threat categories of IUCN Red List. The results of this study are further discussed in view of the conservation and management of ethnobotanical species.
\end{abstract}

Keywords: ethnobotanical species, collection, marketing, supply chain; conservation, Pachmarhi Biosphere Reserve

\section{Introduction}

Forests are not merely a useful bio-resource to the forest dwellers and other tribal communities but a whole way of life, which includes their culture, society, food, income and employment. They worship forests as their Gods and Goddesses in appreciation of sustaining their life [1]. The dependency of forest dwellers and other tribal communities on the forests is deeply interwoven with their traditional and indigenous knowledge, which they acquired through generations from their elders $[2,3,4]$. The indigenous knowledge evolved by these communities is predominantly influenced by the natural forces [5] and has been ecologically sustainable [2]. With the passage of time changes crept in the traditional way of dependency of these communities on the natural resources for basic needs of life [6]. With the advent of evolutionary changes in the human civilization such as urbanization, globalization and industrialization, the lives of these indigenous communities do not left uninfluenced by these changes $[7,8]$.

In developing countries, such as India, most of the tribal population still lives below poverty line, as they have very limited sources of income, mainly collection of forest produce, marginal agriculture and daily-wage labour $[4,9,10]$. The tribal people constitute the core of the poor who live in poverty, poor health and sanitation, illiteracy and other social problems. Their economy is merely for subsistence [11]. Over 270 million people in India are dependent on forest produce for a living [12]. On many occasions, the crop does not yield expected returns due to poor irrigation facilities and unpredictable weather conditions [13]. In such cases, their dependence on forests increases as the forest-produce mainly meets their livelihood and economic needs at such times.

In view of the present socio-economic changes due to several reasons, the present study, therefore, focuses on collection and supply chain of ethno-botanical species by the tribal communities in the buffer zone areas of Pachmarhi Biosphere Reserve (PBR) of India. This provides a vivid picture of anthropogenic connections and subsequent pressures on such useful botanicals in their natural habitats. Furthermore, it also portrays the present scenario of ethnobotanical species and dependency of local people, living in the buffer zone of PBR, on the surrounding forests.

\section{Methodology}

\subsection{Study Area}

The Pachmarhi Biosphere Reserve (PBR), one of the 15 biosphere reserves of India, lies between $20^{\circ} 10^{\prime}$ to $22^{\circ} 50^{\prime}$ $\mathrm{N}$ latitude and $77^{\circ} 45^{\prime}$ to $78^{\circ} 56^{\prime} \mathrm{E}$ longitude. It spans over 3 districts of Madhya Pradesh - Hoshangabad, Betul, and Chhindwara (Figure 1). The total geographical area of PBR is $4926.28 \mathrm{sq} \mathrm{km}$, of which $524.37 \mathrm{sq} \mathrm{km}$ is under the 
core zone and remaining 4462.93sq $\mathrm{km}$ comprises the buffer zone. PBR consists of three wildlife conservation units, the Satpura National Park $(524.37 \mathrm{sq} \mathrm{km})$, the Bori Wildlife Sanctuary (518.00sq km), and the Pachmarhi Sanctuary (461.37sq km). Satpuda National Park is designated as the core zone of PBR and the remaining area including the Bori and Pachmarhi sanctuaries constitute the buffer zone $[1,4]$. In general, the temperature of PBR ranges from 11 to $42^{\circ} \mathrm{C}$ [14].

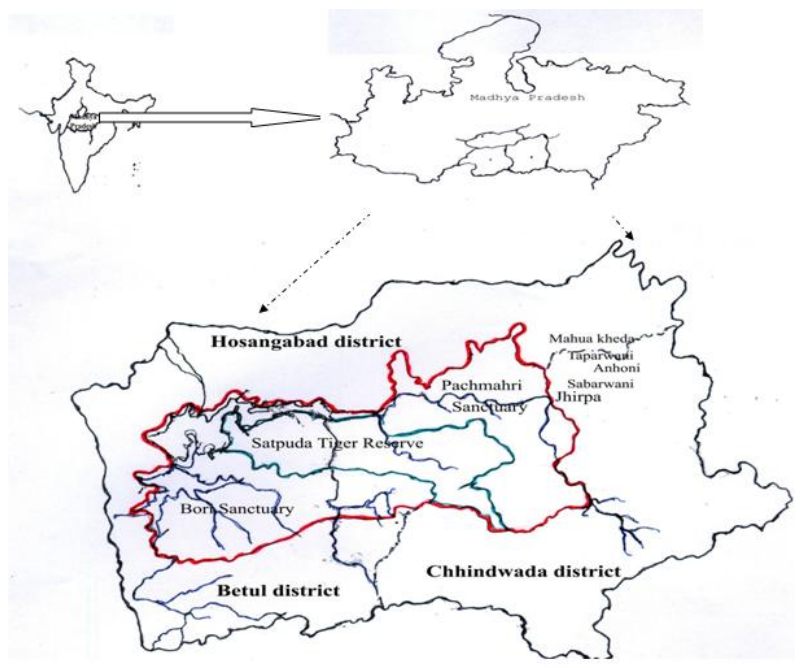

Figure 1. Location map of the Pachmarhi Biosphere Reserve in India

PBR endows with rich plant and animal diversity. It is equally known for its cultural diversity, as it is inhabited by number of tribal and non-tribal communities. The major tribal group is Gond in the study area. Because of the numerical strength, the Gond tribes dominate the central parts of India and the Central Province was known as Gondwana state, as the Gond ruled this part of India in the past. The social organization of Gond reveals that they are divided into clans, such as, Arpanche, Dhurwe, Erpachi, Imne, Karskoley, Sarbeyan, Sarada, Barkare, Barkey, Batti, Eke, Kumre, Porta and Tekam.

\subsection{Survey Methods}

\subsubsection{Questionnaire Survey}

The questionnaire surveys were conducted in the villages of the buffer zone area of PBR. A total 10 villages namely Sawarwani, Shahwan, Fatepur, Singhpur, Anhoni, Bandi, Deokoh Bodalkachhar, Khara and Taperwani were selected for intensive study. The selected villages were dominated by tribal communities, mostly Gond and Mawasi with their offshoots. During the surveys the local people were asked about the ethno-botanical species they used to collect from the forests and surrounding areas for their own consumption and for commercial purpose. The questions were mainly based upon the plant parts collected, method of collection, season of collection, total time spent in collection, main uses of the collected ethno-botanical species, processing of raw materials, marketing channels and price trends of the ethno-botanical species.

\subsubsection{Interviews with the Local Traders}

The villagers sold their collection of ethno-botanical species to some specific local traders and their agents. Such starting link of the trade chain was identified for the supply chain analysis. There were a few local traders who dealt with the villagers directly and hence they were individually interviewed. Besides, the local market survey was also conducted. The traders were probed about the ethno-botanical species of the buffer zone area of PBR in trade, and their rates per unit at which they used to buy them from the harvesters.

\subsubsection{Tribal Market and Weekly 'Haat' Survey}

The tribal markets and 'weekly haats' (haat is a local term for trade centre) were the places where the local people sold their agricultural and forest produce and bought the stuff of their daily needs. These markets were visited and surveyed for the price trends in ethnobotanical species sold weekly. The traders were inquired about the trade chain followed by them to supply the ethnobotanicals to their final processing units.

\section{Results}

The present study documented 14 ethno-botanical species, which were traded from the selected villages of the buffer zone area of PBR (Table 1). Species with parts collected, seasons of collection, total time spent in collection, and uses of all 14 ethno-botanical species are summarized in Table 1. The ethno-botanical species are described below based on diverse parameters including plant parts collected and season of collection.

\subsection{Plant Parts Collected}

Different plant parts were collected by the local people for their own consumption and trade. A total 5 ethnobotanical species such as Acacia nilotica, Anogeissus latifolia, Sterculia urens, Terminalia tomentosa and Terminalia arjuna were sought for the collection of gums. In Acacia nilotica and Terminalia tomentosa, the gums oozed out by itself from their branches without making any cut on the tree, which was collected by the local people. Anogeissus latifolia, Sterculia urens and Terminalia arjuna were treated conventionally for collection of gums by making cuts into the stem. The trade in gum generally had brought good returns to the local people.

Seeds of Cassia tora, Psoralea corylifolia and Celastrus paniculata were collected. The rhizome of Dioscorea daemona was collected and processed to make chips for selling in the market. The leaves of Diospyros melanoxylon was collected exclusively for sale, which had a separate marketing system among the ethnobotanicals collected from the forests. The flowers of Madhuca indica and aboveground parts of Baber grass (Ischaemum angustifolum) were collected for trade as well as for own use. The fruits of Buchanania lanzan, Diospyros melanoxylon, Phyllanthus officinalis and Madhuca indica were collected for trade and own consumption. In case of Buchanania lanzan, the plant part collected was fruit but the tradable part was seed. The fruits of some species such as Balanites roxburghii, Trichosanthes palmata and Cassia fistula were consumed by the locals themselves, and generally were not in trade.

\subsection{Season of Collection}


The extraction of forest resources mainly depended on seasonal variations. Starting from the initial month of a year, Celastrus paniculata was harvested in the month of January-February. The gum of Anogeissus latifolia was tapped during February-March. It is followed by the collection of flowers of Madhuca indica, which was done in March-April. Continuing with Madhuca indica its fruits were collected during April-May. Along with this, the months of April-May were also considered suitable for tapping of gums from Acacia nilotica and Terminalia tomentosa. Fruits of Balanites roxburghii were also collected in the month of May. People got engaged in the collection of Buchanania lanzan in May-June. Thereafter, any appreciable collections of tradable forest resources in the succeeding months were not observed till November.

Out of 14 tradable ethno-botanical species, five species were collected in November and December. These species were Cassia tora, Dioscorea daemona, Ischaemum angustifolum, Psoralea corylifolia and Phyllanthus officinalis. From this, it can be deduced that November and December were the most important months of a year from trade point of view. Two ethno-botanical species such as Sterculia urens and Terminalia arjuna were collected throughout the year.

Table 1. Plant part collected, collection season, time spent in collection, uses and sale price of ethno-botanical species in buffer zone of PBR

\begin{tabular}{|c|c|c|c|c|c|c|c|}
\hline $\begin{array}{l}\text { S. } \\
\text { No. }\end{array}$ & Species & Local name & $\begin{array}{l}\text { Plant part } \\
\text { collected }\end{array}$ & $\begin{array}{l}\text { Collection } \\
\text { season }\end{array}$ & $\begin{array}{l}\text { Time spent in } \\
\text { collection }\end{array}$ & Uses & $\begin{array}{c}\text { Sale price } \\
\text { by villager } \\
(\mathrm{kg})\end{array}$ \\
\hline 1 & $\begin{array}{l}\text { Acacia } \\
\text { nilotica }\end{array}$ & Babool & $\begin{array}{c}\text { Gum } \\
\text { (branch) }\end{array}$ & April-May & Whole day & During delivery & $120 / \mathrm{kg}$ \\
\hline 2 & $\begin{array}{l}\text { Anogeissus } \\
\text { latifolia }\end{array}$ & Dhaora & Gum & February-March & Whole day & Edible & $100 / \mathrm{kg}$ \\
\hline 3 & $\begin{array}{l}\text { Buchanania } \\
\text { lanzan }\end{array}$ & $\begin{array}{l}\text { Achar, } \\
\text { Chironji }\end{array}$ & Fruit & May-June & Whole day & Seeds edible & $20-25 / \mathrm{kg}$ \\
\hline 4 & Cassia tora & Ponar & Seed & November-December & $1-2 \mathrm{hrs}$ & $\begin{array}{l}\text { Vegetable, ingredient of } \\
\text { coffee }\end{array}$ & $5-6 / \mathrm{kg}$ \\
\hline 5 & $\begin{array}{l}\text { Celastrus } \\
\text { paniculata }\end{array}$ & Maarkangni & Seed & January-February & Whole day & Oil yielding, cut-wounds & $50-60 / \mathrm{kg}$ \\
\hline 6 & $\begin{array}{l}\text { Dioscorea } \\
\text { daemona }\end{array}$ & Bechandi & Rhizome & November-December & Whole day & $\begin{array}{l}\text { Chips used during } \\
\text { delivery }\end{array}$ & $120 / \mathrm{kg}$ \\
\hline 7 & $\begin{array}{l}\text { Diospyros } \\
\text { melanoxylon }\end{array}$ & Tendu & Fruit, Leaf & April-May & $7-8 \mathrm{hrs}$ & $\begin{array}{c}\text { Fruit - edible } \\
\text { Leaf - smoke (bidi) }\end{array}$ & $\begin{array}{c}75 / 100 \\
\text { bundles of } \\
\text { leaves }\end{array}$ \\
\hline 8 & $\begin{array}{l}\text { Phyllanthus } \\
\text { officinalis }\end{array}$ & Aonla & Fruit & November-December & Whole day & Fuelwood, pickle & $15-20 / \mathrm{kg}$ \\
\hline 9 & $\begin{array}{l}\text { Ischaemum } \\
\text { angustifolum }\end{array}$ & Baber grass & Whole plant & November-December & $4 \mathrm{hrs} /$ whole day & Rope & $5 / \mathrm{kg}$ \\
\hline \multirow{2}{*}{10} & \multirow{2}{*}{$\begin{array}{l}\text { Madhuca } \\
\text { indica }\end{array}$} & \multirow{2}{*}{ Mahua } & Flower & March-April & $5-6 \mathrm{hrs}$ & Edible, liquor & $12 / \mathrm{kg}$ \\
\hline & & & Fruit & April-May & $5-6 \mathrm{hrs}$ & Edible & $10-12 / \mathrm{kg}$ \\
\hline 11 & $\begin{array}{l}\text { Psoralea } \\
\text { corylifolia }\end{array}$ & Baksi & Seed & November-December & $1-2 \mathrm{hrs}$ & Agarbatti (aroma) & $5-6 / \mathrm{kg}$ \\
\hline 12 & $\begin{array}{l}\text { Sterculia } \\
\text { urens }\end{array}$ & Kullu & Gum (Stem) & Round the year & $\begin{array}{l}\text { Summer: } 1-1.5 \mathrm{hrs,} \\
\text { Winter: } 4-5 \mathrm{hrs}\end{array}$ & $\begin{array}{l}\text { Gynecological disorders, } \\
\text { rope }\end{array}$ & $200 / \mathrm{kg}$ \\
\hline 13 & $\begin{array}{l}\text { Terminalia } \\
\text { arjuna }\end{array}$ & Arjun/Koha & Gum & Round the year & 35 Minutes & Joint pains \& injuries & $120 / \mathrm{kg}$ \\
\hline 14 & $\begin{array}{l}\text { Terminalia } \\
\text { tomentosa }\end{array}$ & Saja & $\begin{array}{c}\text { Gum } \\
\text { (Branch) }\end{array}$ & April-May & Whole day & Used during delivery & $120 / \mathrm{kg}$ \\
\hline
\end{tabular}

\subsection{Time Spent in collection}

During collection season, the local people spent major part of the day in searching and gathering of ethnobotanicals. According to villagers, it had become difficult to search and collect ethnobotanicals from past couple of years. Fifty percent of tradable ethno-botanical species such as Acacia nilotica, Anogeissus latifolia, Buchanania lanzan, Dioscorea daemona, Dyospyros melanoxylon, Phyllanthus officinalis, Ischaemum angustifolum and Terminalia tomentosa demanded whole day labour. Some ethno-botanical species required comparatively less time, from half an hour to a few hours. Only Cassia fistula needed 3-4 days for collection, as it was quite difficult to find out its growing sites in the forests.

\subsection{Traditional Harvesting Practices of Ethno-botanicals}

The manual efforts were highly involved in the collection of ethno-botanical species from the forests (Table 2). There were some ethno-botanical species, which were collected in a similar manner while some needed particular method to be followed for beneficial collection. On the basis of the method of collection, the ethno-botanical species are enlisted in Table 2. Cassia tora, Ischaemum angustifolum and Psoralea corylifolia were collected by cutting with 'hasiya' (a type of a sickle), fruits and flowers of Madhuca indica and fruits of Cassia fistula were collected by picking up from the ground with hands, fruits of Phyllanthus officinalis and seeds of Celastrus paniculata were collected with the help of stick 
and the bark of Cordia macleodii was collected with the help of an axe. Earlier, the frozen gum attached on the branches and trunk was collected, hence there was least harm to the trees.

\subsection{Processing of Collected Species}

The processing of forest produce was started right from the home of harvesters in which women folk were more involved than men. In some cases, the processing of raw materials was also done by the middlemen and even by the retailers as per the requirements of the products and demand of the market. The processing of some plant species, especially used for medicinal purpose, needed special care as their chemical composition could even render them poisonous if not handled properly.

Table 2. Traditional harvesting techniques of ethnobotanial species

\begin{tabular}{|c|c|c|}
\hline S. No & Methods of collection & Ethnobotanical species and their parts collected \\
\hline 1 & Cut by sickle & $\begin{array}{c}\text { Cassia tora (seeds), Ischaemum angustifolum (Whole plant), Psoralea } \\
\text { corylifolia (Seeds) }\end{array}$ \\
\hline 2 & Picked up with hands & Madhuca indica (Fruits and Flowers), \\
\hline 3 & Collected by hands & $\begin{array}{c}\text { Buchanania lanzan (Fruits), Diospyros melanoxylon (Leaves), } \\
\text { Phyllanthus officinalis (Fruits) }\end{array}$ \\
\hline 4 & Collected by hands and also with the help of stick & Phyllanthus officinalis (Fruits), Celastrus paniculata (Seeds) \\
\hline 5 & Dug out with iron rods & Dioscorea daemona (Tubers) \\
\hline 6 & Collected by slicing with the help of axe & Cordia macleodii (Bark) \\
\hline
\end{tabular}

Some ethno-botanical species were processed at different stages by the different stakeholders. The tuberous root of Dioscorea daemona was collected by the harvesters and kept in water for a day, which made its outer layer soft to peel off easily. The white inner part was again washed to remove any impurities left attached. Thereafter, thin chips were grated out of the tubers and boiled till they became soft. These chips were dried in the bright sunlight for 2-3 days. After drying, the chips became ready to be fried and eaten. The fried chips were sold in the market.

The fruits of Phyllanthus officinalis, Madhuca indica and Buchanania lanzan were dried in the sun for 2-3 days before selling in the market. The dried fruits could be used for longer period of time. The fruits of Phyllanthus officinalis, which were picked before ripening, turned black on drying and yielded low price, as compared to the fruits picked after ripening, which turned reddish after drying. Buchanania lanzan was processed by some of the retailers having possessing machines for peeling off the compact outer layer of seeds. The flowers of Madhuca indica were gathered from 4 a.m. to 10 a.m. as it was believed that the flowers fell down by themselves from the trees during this time duration. These flowers were also dried in sun for 2-3 days before selling in the market or brewing local liquor. Its fruits were eaten raw and the seed kernels were crushed to release edible oil.

The seeds of Psoralea corylifolia, Cassia tora, and Celastrus paniculata were taken out by thrashing their fruits, which got detached from the stems. It was done soon after cutting their stems close to the ground. In case of Psoralea corylifolia, the local traders used to dry up the seeds for 2-3 days after buying it from the collectors. The dried seeds were bought at higher price compared to the fresh seeds by the traders. Ischaemum angustifolum was also dried before making its ropes. Such ropes were kept away from water, as water made the ropes weak and reduce their durability.

The leaves of Diospyros melanoxylon had a unique pattern of packing, which was followed strictly. The healthy leaves were collected without any deformities.
Such leaves were packed in a bundle of 50 leaves placed one over the other. This pattern of packing was followed for avoiding the wear and tear of leaves during storage and transportation before manufacturing the end product. In addition to above processing, the collection of leaves was done from 9.00 a.m. till 1.00 p.m. in the afternoon because it was believed that the leaves lose their quality and value thereafter. The fruits of Diospyros melanoxylon were also consumed but they were not in trade. Either the ripened fruits dropped naturally were eaten or the unripe fruits plucked from mother trees were placed in straw of Cicer arietinum for 4-5 days to ripen.

\subsection{Supply Chain and Marketing Of Ethnobotanicals}

Many ethno-botanical species, originally used by the tribal communities, have now become necessary raw material of the herbal industries. Since these ethnic communities had very limited sources of income, therefore the collection of the ethno-botanical species in demand appeared to them one of the good source to make an additional income. The trade in ethno-botanical species has developed a market set up in which there was a supply-chain starting from the harvesters and ending up in the consuming units. This chain had various interconnecting links of middlemen, traders, retailers and wholesalers. The collected species as documented in Table 1 were being traded through different market channels.

\subsubsection{Village Level Marketing}

On many occasions, people preferred to sell their collections from their villages or more specifically from the doorsteps of their houses. This happened mostly in the cases either when they were not willing to carry their collections to the market due to unavailability of vehicles or they were engaged in some other works. In such cases, the middleman himself or his agent used to go into the village and did all the collections. Such transactions were mainly carried out in prohibited ethno-botanical species. All 3 species sold in such manner were gum-yielding 
species, namely, Acacia nilotica, Sterculia urens and Terminalia tomentosa.

\subsubsection{Marketing Outside the Village}

It was a market place visited by the local people living within $10-15 \mathrm{~km}$ periphery. Jhirpa was such a market place, which got flooded with the primary collectors, the traders and the middlemen on every Saturday. Most of the villagers brought the ethnobotanicals collected by them to sell here and gain some money to buy necessary items of daily use. The local people brought the produce as headloads in sacks or in carts or in jeeps or on bicycles. In market, there were some local traders or middlemen who used to buy their collections. In most cases, the villagers directly approached to a fixed middleman who dealt in ethnobotanicals and had developed a trust in providing the reasonable returns for their collections. But sometimes, the villagers first inquired about the price trends in the market and then sold their collections to the middleman who agreed upon the highest returns. Mostly the market prices of ethnobotanicals were decided by the middleman or local traders according to the price trends in the bigger markets.

Apart from fixed market places, there were 'weekly haats' in which a definite week day was allotted in a sequent to the location of such primary tribal market. There were 7 such market places and the week days allotted to them were Monday to Dhelakhedi, Tuesday to Sanghakeda, Wednesday to Chawalpani, Thursday to Bodalkachhar, Friday to Tamiya, Saturday to Jhirpa and Sunday to Bamni. These weekly-haats were the centre of business of all kinds of daily needs - goods ranging from vegetables to clothes. In the weekly market, generally, 5-6 traders dealt with ethnobotanicals. The local traders related to forest produce were available to buy ethnobotanicals only on the fixed market days. On rest of the week days, they used to do their agricultural and household works.

\subsubsection{Government Involvement in Marketing}

Two ethno-botanical species, Ischaemum angustifolum and Diospyros melanoxylon, were sold to the Forest Department. For the purchase of Diospyros melanoxylon, a person called as 'phad munsi' was appointed among the villagers by the Department. He collected the leaves of Diospyros melanoxylon in the form of bundles and paid fixed amount to the villagers. Similar method was done for Ischaemum angustifolum, which was sold to the Forest Department. The villagers had to gather their collections in a village decided by the Department and they got the price of their collections at that place only.

The trade in forest produce encompassed a large number of medicinal plants, wild edible plants, fibres and exudates from plants. Regarding the supply chain of these commercialized ethno-botanical species, the primary stakeholders were harvesters or the local people of the study area who collected various plants and their parts for their own consumption and simultaneously, for selling according to the demand in the market. These people depended entirely on the local traders for the sale of their collections. The local traders or middlemen purchased the collected plant material from the local people either in primary tribal markets or directly from their homes. The supply chain of ethno-botanical species in the present study area is explained in Figure 2.

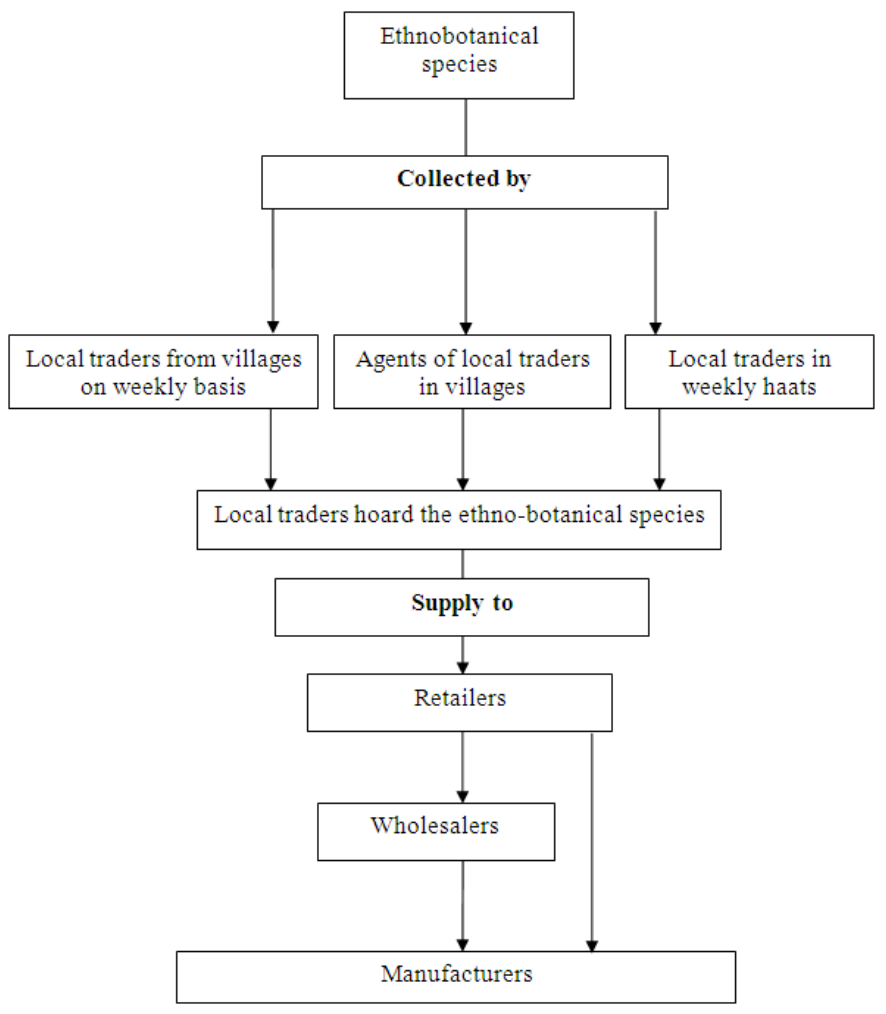

Figure 2. Supply-chain of ethno-botanical species in study area

During the season of collection, transportation of produce was done from the market place itself, but during off-season, the local traders used to hoard the collections for one to two weeks depending upon the storage life of an ethno-botanical species at their homes or stores. After gathering up sufficient quantity of collections they sold 
them to regional traders at Dhelakhedi or Chhindwada. The local traders of the buffer zone area of PBR used to transport such forest produces in small amounts as they had to pass through 4 transit barriers. The illegal trade prevailed in the prohibited ethnobotanicals like gum of Sterculia urens.

The gum yielding species were found to be highly paid species among all traded ethno-botanical species. These include Acacia nilotica, Anogeissus latifolia, Sterculia urens, Terminalia arjuna and Terminalia tomentosa. Among these five, the cost of Sterculia urens was highest. The gum tapping from this species was strictly prohibited and highly penalized under law due to its very less number of trees left in the forests and the tapping of gum renders its bark dry and ultimately it dies off. The stem was chopped deeply at number of places for tapping of gums. Its sale price was `200/kg. The gums of 3 species namely Acacia nilotica, Terminalia arjuna and Terminalia tomentosa were sold together forming mixture of dry gum pieces, which was locally called as 'Satkata'. It was done so because the cost of these gums individually was same $120 / \mathrm{kg}$. The gums were preferred to be sold from home and rarely brought to the open market places.

The leaves of Diospyros melanoxylon were bought by the Forest Department at a fixed price i.e., ' 75 for 100 bundles. Each bundle was consisted of 50 leaves packed in a definite sequence. Forest Department was also the major buyer of Baber grass, which was sold at the price of $5 / \mathrm{kg}$. This was the lowest paid ethno-botanical species. Madhuca indica was another important ethnobotanical for the tribal economy of the Central Indian States. Its flowers, as valued for brewing local liquor, were sold at the rate of $12 / \mathrm{kg}$ while its fruits were sold at $10-12 / \mathrm{kg}$.

The harvesters were the least paid people in the whole trade chain and were exploited by the middlemen as they were less aware about the price trends in the wholesale markets of the herbal raw materials. Moreover, to maximize their profits, the local traders influenced the poor harvesters to increase the quantity of collection of raw materials resulting in the adoption of unsustainable harvesting practices by them which was one of causes of mounting pressure on the forests of the buffer zone area of PBR.

\subsection{Conservation Concerns}

Due to market forces, the forest resources were gradually facing an immense pressure. The trade in ethnobotanicals and market trend has compelled communities to unsustainable harvesting of tradable forest resources for getting maximum returns unlike their ancestors. The methods employed by them to collect ethnobotanicals were sometimes so destructive that after the former year's harvest, the quantity of produce declined so badly that it was difficult to get produce in the later years. This has led to threaten the native flora of the region. Of 14 species in trade 8 belonged to various IUCN Red List categories. Celastrus paniculata was the only ethno-botanical species in trade, which was placed under endangered category, and 4 species such as Buchanania lanzan, Dioscorea daemona, Phyllanthus officinalis and Terminalia arjuna belonged to vulnerable category. Rest 3 species such as Anogeissus latifolia, Madhuca indica and
Sterculia urens belonged to Lower Risk - Near Threatened categories of IUCN.

\section{Discussion}

Earlier, there was never a hard core trade in the ethnobotanical species. They were collected for personal use by the households or to barter them for some basic commodities. For instance, it was a common practice in the tribal communities to give some ethno-botanical or forest produce to the cattle-herders for their services of taking cattle for grazing [4]. The desire of large population to use natural products has motivated several phytopharmaceutical and cosmetics enterprises to come up in the market, which has been the basic reason for the commercialization of these ethno-botanical species. The forest resources mainly medicinal plants do have a big market due to its high consumption by the herbal industries, worldwide. With the globalization and competition at the global and national level, the trade in these ethno-botanical species has increased manifold as compared to the situation a decade ago.

There are studies conducted on the trade and marketanalysis of medicinal plants in India [15], and in different countries around the globe [16]. The major outcome brings forward through these studies reflects the growing interests of large number of people in herbal products as they have least side-effects and are natural. This adds values in the commercialization of plant species lesser known to the general population. With due course of time the demand of these ethno-botanical species has increased, worldwide. The annual global export of plants used in pharmaceutical industries is estimated to be $467,000 \mathrm{t}$, in which Asia has the largest contribution in the extraction (by volume) of non wood forest products and China is leading in this context [17]. USA is the one of the leading markets of herbal drugs and for sustaining its $\$ 3$ billion market it uses to import 51,200 therbs each year [16,17].

There are some medicinal plant species which are found in wild and form a major part of global trade such as Ginseng, Artemisia, Aconites etc. The main producers of ginseng in the world are The Republic of Korea, China and the USA. China contributes approximately $40 \%$ to the total world ginseng trade [18]. However, the figures regarding the extraction and trade of the forest resources cannot be estimated precisely due to illegal trade and hesitation in the local harvesters and traders to reveal information [19], therefore much of the quantities of these resources remain unrecorded [20].

The yield of the ethno-botanical species collected from the forests on large scale depends on the weather too. With the changes in weather conditions, the flowering and fruiting time of the plant species get altered and even hampers the quantity of the yield [21,22]. Studies conducted elsewhere have shown that the collection of forest resources is directly related to the seasons [23], and tribal markets contain large amount of different ethnobotanical species according to their season of collection [24]. The harvesters remain vigilant for the collection season so that they can have a good yield without any hassles generated due to the over-ripening or decomposition of the desired collections and harm done to them by the wild animals. There are various other factors 
such as the collection methods, processing of raw materials and value addition to them which can yield higher returns to the harvesters and the local traders.

The transformation in traditional system with blind race of earning money has led to overexploitation of useful species. In India, people collected 5,92,853 metric tonnes (mt) leaf of Diospyros melanoxylon during 2002-2003, which increased to 7,10,109 $\mathrm{mt}$ in 2003-04 [25]. Unfortunately, the leaf collection of Diospyros melanoxylon was declined drastically to 3,12,660 mt and $2,68,464 \mathrm{mt}$ in subsequent years [25], due to unsustainable harvesting practices and overexploitations of past years. At present, the tribal community adjoining the study area demands more prices for the collection of Diospyros melanoxylon, not less than `250 for 100 bundles of leaves instead of ` 75 they are being paid [26].

As the market of the herbal products is expanding, the demand for the required plant species is not possible to be met from the natural resources. Farming of these important species is seemed to be an option for meeting the requirement. However, the cultivated plants may not match the essence and vigour of the plants grown in wild and the pressure on the wild resources will be continued. Circumstances dictate the greater use of traditional knowledge systems and practices can help to sustain the ecosystem and forest resources provided they are used wisely. Combining afforestation, natural regeneration and conservation of forests with right kind of incentives may help the sustainability of these important ethnobotanicals.

\section{Acknowledgements}

I thank Director, Indian Institute of Forest Management, and forest officials of Pachmarhi Biosphere Reserve for help and support. Diksha Bhandari is acknowledged for helping in field-data collection. The project funded under the grant IIFM/RP-Int./CPK/2009-11/04 is duly acknowledged.

\section{References}

[1] C. P. Kala, "Traditional ecological knowledge, sacred groves and conservation of biodiversity in the Pachmarhi Biosphere Reserve of India," Journal of Environmental Protection, Vol. 2, No. 7, 2011, pp. 967-973.

[2] R. Guha, "Forestry in British and post-British India: A historical analysis," Economic and Political Weekly, Vol. 18, No. 44, 1983, pp. 1882-1896.

[3] F. Berkes, "Rethinking community based conservation," Conservation Biology, Vol. 18, No. 3, 2004, 621-630.

[4] C. P. Kala, "Traditional ecological knowledge and conservation of ethnobotanical species in the buffer zone of the Pachmarhi Biosphere Reserve, Madhya Pradesh," A Technical Report. Indian Institute of Forest Management, Bhopal. 194 pp. 2005.

[5] F. Berkes, J. Colding, and C. Folke, "Rediscovery of traditional ecological knowledge as adaptive management," Ecological Applications, Vol. 10, No. 5, 2000, pp. 1251-1262.

[6] C. P. Kala and P. Ratajc, "High altitude biodiversity of the Alps and the Himalayas: ethnobotany, plant distribution and conservation perspective," Biodiversity and Conservation, Vol. 21, No. 4, 2012, pp. 1115-1126.

[7] C. P. Kala, "Indigenous uses, population density, and conservation of threatened medicinal plants in protected areas of the Indian Himalayas," Conservation Biology, Vol. 19, No. 2, 2005, pp. 368378.

[8] C. P. Kala, "Problems and prospects in the conservation and development of the Himalayan medicinal plants sector," International Journal of Sustainable Development, Vol. 9, No. 4, 2006, pp. 370-389.

[9] G. Mathew, "Panchayati Raj institutions and human rights in India," Economic and Political Weekly, Vol. 38, No. 2, 2003, pp. $155-162$.

[10] A. Shah and O. G. Sajitha, "Dwindling forest resources and economic vulnerability among tribal communities in a dry/ subhumid region in India," Journal of International Development, Vol. 21, No. 3, 2009, pp. 419-432.

[11] M. Sahlins, "Hunter-gatherers: Insights from a golden affluent age. Pacific Ecologist," 2009.

http://www.pacificecologist.org/archive/18/pe18-huntergatherers.pdf (accessed on 17 October 2012).

[12] K.S. Shrivastava, "Price tag for tendu, bamboo," Down to Earth, May 15, 2011, http://www.downtoearth.org.in/content/price-tagtendu-bamboo (assessed on 6 June 2012).

[13] C. P. Kala, "Status of an indigenous agro-forestry system in changing climate: A case study of the middle Himalayan region of Tehri Garhwal, India," Journal of Forest Science, Vol. 56, No. 8, 2010, pp. 373-380.

[14] EPCO, "Pachmarhi Biosphere Reserve," Environmental Planning and Co-ordination Organization. Bhopal, India, 2001.

[15] D. K. Ved and G. S. Goraya, "Demand and supply of medicinal plants," Foundation for Revitalization of Local Health Traditions, Bangalore, India, 2008.

[16] D. Lange, "International trade in medicinal and aromatic plants", In: R.J. Bogers, L.E. Craker and D. Lange (eds.), Medicinal and Aromatic Plants, Springer, Netherlands. 2006, pp. 155-170.

[17] FAO, "lobal Forest Resources Assessment 2010," FAO Forestry Paper 163. Food and Agriculture Organization of the United Nations, Rome. 2010, pp 106.

[18] M. Iqbal, "International trade in non-wood forest products-an overview," Forest Products Working Paper 11. Food and Agriculture Organization of the United Nations, Rome. 1993.

[19] A. Lewington, "A review of the importation of medicinal plants and plant extracts into Europe," TRAFFIC International, Cambridge. 1993, 37 p.

[20] P. M. Wehi and W. L. Wehi, "Traditional plant harvesting in contemporary fragmented and urban landscapes," Conservation Biology, Vol. 24, No. 2, 2010, pp. 594-604.

[21] G. Grabherr, "Biodiversity in the high ranges of the Alps: Ethnobotanical and climate change perspectives," Global Environmental Change, Vol. 19, No. 2, 2009, pp. 167-172.

[22] S. Gairola, N. M. Shariff, A. Bhatt and C. P. Kala, "Influence of climate change on production of secondary chemicals in high altitude medicinal plants: Issues needs immediate attention," Journal of Medicinal Plants Research, Vol. 4, No. 18, 2010 pp. 1825-1829.

[23] A. Awasthi, S. K. Uniyal, G. S. Rawat and A. Rajvanshi, "Forest resource availability and its use by the migratory villages of Uttarkashi, Garhwal Himalaya (India)," Forest Ecology and Management, Vol. 174, 2003, pp. 13-24.

[24] S. K. Masih, C. B. Sharma and M. C. Sharma, "NTFP and their price trends in primary tribal markets," Journal of Non-Timber Forest Products, 8(3/4): 2001, pp. 159-168.

[25] P. G. Lal and N. C. Wilson, "The Perverse Economics of the Bidi and Tendu Trade," Economic and Political Weekly, XLVII (2), 2012, pp. 77-80.

[26] A. Pallavi, "Tribals, forest department at loggerheads at tendu leaves," Down to Earth, May 29. 2012. http://www.downtoearth.org.in/content/tribals-forest-departmentloggerheads-over-tendu-leaves (accessed on 6 June 2012) 